\title{
The Course Council: An Example of Student-Centered Learning
}

Deborah Himes

Brigham Young University - Provo, deborah-himes@byu.edu

Barbara Heise

Brigham Young University - Provo

Follow this and additional works at: https://scholarsarchive.byu.edu/facpub

Part of the Nursing Commons

\section{Original Publication Citation}

Heise, B., Himes, D. O., (2010) The Course Council: An Example of Student-Centered Learning. Journal of Nursing Education. 49(6), pp. 343-345. doi: 10.3928/01484834-20100115-04

\section{BYU ScholarsArchive Citation}

Himes, Deborah and Heise, Barbara, "The Course Council: An Example of Student-Centered Learning" (2010). Faculty Publications. 1753.

https://scholarsarchive.byu.edu/facpub/1753

This Peer-Reviewed Article is brought to you for free and open access by BYU ScholarsArchive. It has been accepted for inclusion in Faculty Publications by an authorized administrator of BYU ScholarsArchive. For more information, please contact ellen_amatangelo@byu.edu. 


\title{
The Course Council: An Example of Student-Centered Learning
}

\author{
Barbara Heise, PhD, APRN, BC; and Deborah Himes, MSN, APRN, BC
}

\begin{abstract}
To promote student-centered learning, a course council was established in a beginning undergraduate nursing course. A student representative was selected by peers to attend a monthly course council meeting with faculty. Representatives were asked to query classmates in their section of eight students regarding opinions, questions, and concerns about the course and then bring those views to the council. In this monthly, small group, open dialogue setting, students spoke freely about experiences in the classroom, laboratory, and clinical settings. The stage was set for reflection, problem solving, and decision making involving students and faculty. Student input led to meaningful course changes, provided opportunities for students to learn from one another, and fostered critical thinking and professional responsibility. The course council approach was successful and has been expanded to include other nursing courses.
\end{abstract}

Despite a body of evidence sup- porting the power and validity of student-centered learning models for education, most nursing curricula continue to focus on content as opposed to the outcomes of student learning. Nurse educators must shift their focus from content-centered teaching to student-centered learning if they expect to prepare nurses who are able to do or, in other words, synthesize and apply the complex knowledge to real-life situations as opposed to nurses who simply know (Candela, Salley, \& Benzel-lindley, 2006, p. 60).

Student-centered learning develops critical thinking skills (Mcdonald, 2007). This shift in focus from teacher to student-centered learning empowers students to take a more active role in decisions about what and how they learn. Student-centered learning enables students to participate actively in the learning process and requires nurse educators to begin at the point of the lived experience of students and then create a mentoring environment that empowers students to develop caring, communication, critical thinking, technological, problem solving, lifelong learning, and professional behavior and account- ability skills (Schaefer \& Zygmont, 2003; Young \& Paterson, 2006). Stu- dents and educators collaborate to create a community of learning that is continuously evolving, with an ultimate goal for students to develop in- dependence that prepares them for a "lifetime of personal and professional development" (Penn, 2008, p. 108).

Student-centered learning is based on principles of social and cognitive constructivism theories, which assert that students' prior knowledge is the basis for learning and is a creative relational process. Student-centered learning mirrors and promotes the paradigm shift from nurse-centered to client-centered care (Young \& Paterson, 2006).

Faculty supporting student- centered learning follow four basic tenets. First, nurse educators who promote student-centered learning recognize students are not blank slates but come with prior experiences. This is where nurse educators must begin to guide their students. Second, educators foster professional- ism in students, helping them come to value lifelong learning. Third, professional responsibility develops as nurse educators promote selfawareness through reflection and place more responsibility for evaluation on students. Finally, educators provide the opportunity for students to learn from one another.

Educators who provide these opportunities promote the development of traits that are necessary for students to become professional nurses who are patient-centered (Young \& Paterson, 2006). These student- centered learning concepts are reflected in the creation of a course council.

\section{The Process}

The course council was created as a means to have an ongoing evaluation of a beginning undergraduate nursing course. accepted suggestions were quickly instituted. thus, the purposes of the course council were to:

- Provide a small group environment for communication between students and faculty.

- Empower students to have an active role in course construction.

- Make course improvements based on student and faculty collabo- ration.

- $\quad$ Promote professional leader- ship skills.

- Facilitate critical thinking skills to solve course-related issues.

The course council was not intended to limit students' direct access to faculty. Students were encouraged to 
contact faculty directly if they wanted to meet individually with faculty.

One student from each of eight clinicalnursing sections was selected by theirpeerstorepresent the section and serve as liaisons between nursing students and faculty. The responsibilities of student representatives to thecouncil were to attendeach course councilmeeting, toactively seek their fellow students' concerns and feed- back on the course, to submit agenda items prior to the council meetings, to inform their peers of topics dis- cussed at the meetings as well as any changes instituted in the course, and to act as a resource for their section. a teaching assistant took minutes and distributed them to the coursecouncil via e-mail within 1 day of the meeting.

Initially, the course council met five times during the semester for approximately 1 hour per session. in subsequent semesters, council meetings were held on a monthly basis. a small grant from the university faculty development center was used to purchase food for the council meetings during the first semester to act as an incentive for students to attend. Later, food was not provided as it was deemed unnecessary.

In addition to the course council, mid-term and end-of-semester electronic student evaluations were con- ducted. Mid-term student comments were taken back to the entire class by using an audience response system (i-clicker) method. taking student evaluations back to all students is an important step because not all suggestions reflect the majority point of view. For example, some students wanted weekly quizzes instead of examinations, and some wanted quizzes via i-clicker questions for no points so they could practice and discuss rationales in class. Course changes were made after mid-term evaluations as well as after course council consensus.

\section{Outcomes}

Based on collaboration between students and faculty, the course continues to evolve. Student representatives bring questions and concerns to the table and faculty provide immediate feedback. Although faculty cannot honor every request for change, students are provided a rationale, based on sound educational theory and principles.

Multiple outcomes were achieved that parallel the basic tenets of student-centered learning theory. First, faculty members came to understand student experiences with face-to-face interaction. In the course council setting, representatives were able to share worries and concerns related to their lived experience as new nursing students. This was a safe environment where concerns could be addressed personally. For example, some students expressed concern about not knowing what to do in the clinical setting. Student representatives were able to couch their concern by saying, "Some people in my group worry that..." themes discussed in the course council often were brought to the class as a whole.

Second, students developed skills necessary for lifelong learning. As professional nurses, students will need to continue to build knowledge and skills throughout their careers. As nurses seek to affect practice changes based on new knowledge, they will need the ability to express needs, work in groups, and build consensus. In this setting, students were able to affect positive changes that promoted learning within their course. For example, students expressed concerns regarding the number of clinical assignments. A discussion ensued about the importance of reflective writing to critical thinking skills. Faculty determined the learning objectives for the course could be adequately met with fewer written papers. The end result was decreasing the number of reflective writing papers and adding a group discussion to replace one of the formal papers. Students exhibited professional behavior by helping to choose and shape learning experiences, an essential trait of lifelong learners.

Third, students participated in evaluating their own learning in a professional manner. They recognized stress levels were impeding their learning. Students requested more coordination between classes given during the same semester. As a result, faculty synchronized examination schedules so they did not overlap. In addition, a 4-hour nurture-the-nurse seminar that taught students how to deal with stress using relaxation techniques and other holistic practices was in danger of being eliminated. During course council sessions, students voiced apprehension regarding their stress levels, which sparked a transfer of the nurture-the-nurse seminar to another course to preserve it. This seminar has been universally applauded by nursing students.

Finally, students were provided the opportunity to learn from each other. Students' concerns about not knowing what to do in the clinical setting were addressed in the council by peers who shared their experiences from different clinical sites. They were able to suggest to their classmates ways to be proactive in seeking learning opportunities.

Closer relationships were fostered between students and faculty built on respect and trust. During the past 3 years of the course council's existence, many students have commented that they really appreciated the faculty listening and acting on their concerns. Following initial implementation of the course council, students requested this 
consistent and ongoing student-faculty communication include other nursing courses. Consequently, the course council was expanded to include nursing faculty from other courses during the same semester.

Although we did not quantitatively measure changes in morale and satisfaction of both students and faculty, based on qualitative data, students were satisfied with their role in their own learning. Students' comments reflected their satisfaction with the course council and the courses involved, and students requested the course council be available in other semesters in the nursing program. Four courses taught concurrently now participate.

Faculty opinions of the course council method to promote student- centered learning were mixed. Most faculty thought student empowerment, engagement, and collaboration were beneficial. The course council allows students to model professional behavior associated with quality improvement and to demonstrate leadership skills by bringing suggestions from their peers to the council. The council format allows the course to be dynamic and evolve meeting learners' needs within a given semester. Penn (2008) suggests educators participating in student-centered learning should encourage feedback frequently, at least weekly.

Although many faculty members believed mid-term and end-of- semester evaluations were sufficient, end-ofsemester evaluations do nothing for current students. Mid-term evaluations, which are usually anonymous, allow faculty to make minor course revisions. However, neither of these evaluation models allow for development of lifelong learning or establishment of a community of learners. The course council is one method of providing continuous feedback that promotes student-centered learning to occur (Penn, 2008).

\section{Implications for Faculty}

Faculty members are challenged to add one more meeting into their already overfilled schedule. The demands of staying current with medical and nursing research to teach up-to-date information as well as citizenship and scholarship loads can be enormous. However, in a cost- benefit examination, spending 1 hour per month implementing the course council can provide great rewards for both students and faculty.

Development of a course council is a simple process in which students and faculty meet in a small group set- ting. A faculty concern was that the course council helped only the eight students who attended. However, the entire class was involved when their peers asked them for suggestions to improve the course and when key is- sues were brought back to the entire class for discussion. The council pro- vided a means to obtain insight and information thatmaynotbegained in any otherway.

As nurse educators, when we receive student evaluations of our course, the first reaction may be negative: "I have been teaching for many years," and "these students do not know what is best for them." Hoverer, on reflection, the best nurse educators view counseling with students as another way to reach the common goal of guiding students to become caring, independent, and professional nurses. Student-centered learning assists students and educators to continue to evolve.

\section{Conclusion}

The course council was integrated into a beginning nursing course to provide student-centered learning. This creative approach to student- centered learning resulted in a win- win situation. Students had a voice in the assessment and evaluation of their learning objectives and clinical assignments through the course council. Faculty developed stronger relationships with students and gained significant information to strengthen student-centered learning in the course. Simple changes in courses often made life easier for the students and enhanced learning. The course council provides an- other means to engage student in their own learning. Future research should measure student and faculty satisfaction with the course council method.

Candela, 1., dalley, K., \& Benzel-lindley, J. (2006). a case for learning-centered curricula. Journal of Nursing Educa-tion, 45, 59-66.

Mcdonald, M.E. (2007). The nurse educa- tor's guide to assessing learning out- comes ( $2^{\text {nd }}$ ed.). Boston, Ma: Jones and Bartlett.

Penn, B.K. (2008). Mastering the teaching role: A guide for nurse educators. Phila- delphia, Pa: davis.

Schaefer, K.M., \& Zygmont, d. (2003). analyzing the teaching style of nurs- ing faculty: does it promote a studentcentered or teacher-centered learning environment? Nursing Education Per- spectives, 24, 238-245.

Young, 1.E., \& Paterson, B.l. (2006). Teaching nursing: Developing a stu- dent-centered learning environment. Philadelphia, Pa: lippincott Williams \& Wilkins. 